\title{
EVALUATION OF MARKET EFFICIENCY AND TRADING BEHAVIOR OF INVESTORS: EVIDENCE FROM BORSA ISTANBUL
}

\author{
PIYYSA ETKINLIIĞİNIN VE YATIRIMCILARIN ALIM-SATIM \\ DAVRANIŞININ DEĞERLENDİRILMESİ: BORSA İSTANBUL ÖRNEĞİ
}

Yusuf VARLI*

\begin{abstract}
After the financial crisis of 2007-08, debates on structures and characteristics of financial markets have become the subject of much concern in both industry and academia. One of the most debated issues related to financial markets is whether they are efficient or not. With an intent to enter into discussions, this paper evaluates the market efficiency by using individual and institutional trade data from a specific stock exchange, namely Borsa Istanbul. To do so, we first form several measures of market efficiency through daily investor data covering five years. By using these measures, we show that there is a negative relationship between market efficiency and turnover. That is, the more efficient the market, the lower the turnover. This result contributes to the debate of irrationality of investor behavior. The data also suggests that the efficiency in Borsa Istanbul has been increasing after the crisis, showing that the effect of the crisis has been vanishing as time passes.
\end{abstract}

Keywords: Market Efficiency, Investor Behavior, Stock Trading, Turnover, Stock Exchange, Borsa Istanbul.

JEL Codes: G10, G11, G12, G14.

\section{Öz}

2007-08 finansal krizinin ardından, finansal piyasalarda yapılar ve karakteristikler üzerine gerçekleştirilen tartışmalar hem sanayi hem de akademik çevrelerde oldukça önemli bir konu haline gelmiştir. Finansal piyasalar ile alakalı en çok tartışılan konulardan biri de piyasaların etkin olup olmadıklarıdır. Bu makale, ilgili tartışmalarda yer almak niyetiyle, belirli bir borsadaki - Borsa İstanbul - bireysel ve kurumsal alım-satım

* Assistant Professor. Ibn Haldun University, School of Humanities and Social Sciences, Department of Economics. Email: yusuf.varli@ihu.edu.tr 
verilerini kullanmak suretiyle piyasa etkinliğini değerlendirmektedir. Bunu yapmak için, ilk olarak, beş yıllık bir döneme ilişkin günlük yatırımcı verileri aracılığıyla birkaç piyasa etkinliği ölçüsü oluşturulmuştur. Bu ölçüler kullanarak, piyasa etkinliği ile alım-satım işlem hızı arasında olumsuz bir ilişki olduğu gösterilmiştir. Yani, piyasa ne kadar etkin ise, alım-satım da o kadar düşük olmaktadır. Bu sonuç, yatırımcı davranışının rasyonalitesine dair yapılan tartışılmalara katkıda bulunmaktadır. Veriler ayrıca, Borsa İstanbul'daki etkinliğin kriz sonrasında arttığını ve zaman içerisinde krizin etkisinin giderek azaldığını ortaya koymaktadır.

Anahtar Kelimeler: Piyasa Etkinliği, Yatırımcı Davranışı, Hisse Senedi Alım-Satımı, İşlem Hızı, Hisse Senedi Borsas1, Borsa İstanbul.

JEL Kodları: G10, G11, G12, G14.

\section{INTRODUCTION}

The recent financial crisis has revealed the need of understanding the structure of financial markets. Analyses in both the academia and the industry have re-focused on the basics of definitions, descriptions and theories. One of the things which have come up for discussion in recent years is Efficient Market Hypothesis (see Fama (1970)). There are several studies (i.e., Basu (1977) and Fama (1991)) that are trying to question the relevance of the hypothesis. Our study aims to define market efficiency considering market beating conditions. We also examine the link between the market efficiency and trading behavior of investors.

Most of the literature for the market efficiency emphasizes the role of informational efficiency. While Fama (1970) has an evidence of weak form and semi-strong form efficiencies, Fama (1991) states the stronger form of efficiency. Another way to define the efficiency is to consider market beating situations. According to Statman (2010), "The modest definition of efficient markets is their definition as unbeatable markets". Coval et al. (2005) also employs the market beating conditions for the definition of market efficiency.

Trading volume on the global markets seems high, perhaps higher than that can be explained by models of rational markets (Odean (1999)). Glaser and Weber (2007) conclude that the rational motives for trade were not sufficient to explain the high trading volume in the stock markets. Benos (1998) and Odean (1998) propose that, due to their overconfidence, investors will trade too much. Other literature focuses on the trading behavior of investors (See Barber and Odean (2001), Chuang and Susmel (2011))

Literature that links the market efficiency with trading (or investor turnover) is very scarce and insufficient. Jahnke (1994) indicates that if a market is efficient, portfolio turnover decreases in order to meet liquidity needs. In an efficient market, Damodaran (2002) remarks the strategy of trade minimization. He indicates that, not trading would be superior to a strategy that required frequent trading.

In this study, we begin with presenting the descriptive statistics of return and turnover for the investors in a specific stock market. We define and describe the efficiency for the given market 
using several ways. Using 5 years data in between 2008-2012, it is found that the efficiency in Borsa Istanbul increases as the time goes by. We also suspect that there is an inverse relationship between the market efficiency and trading behavior of investors. In other words, we claim that the turnover is negatively affected by the efficiency. Borsa Istanbul supports our claim that the turnover decreases as it becomes more efficient.

The outline of the study is as follows: Section 2 presents the detail of data and methodology. Here we describe the evaluation of market efficiency and analysis for trading behavior of investors. In Section 3, we provide estimation results, and finally Section 4 contains the conclusion.

\section{DATA AND METHODOLOGY}

\section{I. DATA}

The source of the data used in this study is Central Securities Depositories (MKK), where all the stocks listed on Borsa Istanbul are held electronically on behalf of investors. Number of stock investors in Turkey was 1,091,950 (as of the end of 2012) which is the composition of individual investors (\# 1,086,400) and institutional investors (\# 5,550).

For this study, individuals who had portfolio amount more than TRY 1,000 ( USD 500) and traded at least once in between 2008 and 2012 are selected. We randomly select 25,000 individuals from these investors and the selection of the data is preserved under stratified random data characteristics such as the age, portfolio size distribution of the sample is the same in the population. For the institutional investors, we employ the data of all institutional investors (\# 5550).

Our data is daily and consists of non-holiday regular weekdays (\# 1259 days) between 01.01.2008 and 31.12.2012. All variables in this study are calculated daily, contrary to the most of the literature which uses monthly data. Higher frequency is an advantage for us to have clearer picture for the performance of investors.

The data set includes daily positions (by stocks), daily sales and purchases for each stock in the portfolios for each investor. We also have information about some of the demographics (Age, nationality etc.) of investors.

\subsection{METHODOLOGY}

\subsection{ADJUSTED RETURN}

Daily raw returns of portfolios are defined as follows:

where $r_{i t}$ is the daily return for stock $i$ in day $t$. Also, $p_{i j t}$ represents the weight that was calculated by dividing the end-of-day $t$ market value for stock $i$ to the end-of-day $t$ market value of portfolio held by investor $j$. And $s_{j t}$ is the number of stocks held by investor $j$ at day $t$. 
Market adjusted returns of individual $j$ are calculated daily as follows:

where $r_{t}^{m}$ denotes corresponding daily rate of return of the market (or main broad value stock index in the market).

Having calculated market adjusted daily returns in Equation (2) for each day $t[1,2, \ldots, 1259]$, we calculate the daily average return $\bar{r}_{t}$ for investors as:

where $J$ represents the total number of investors. Note that the "average return" is market adjusted as in Equation (2).

\subsubsection{EVALUATION OF MARKET EFFICIENCY}

Since we have detailed data of investors (e.g., daily positions (by stocks), daily sales and purchases) we can define the efficiency using investor-side information.

Under the definition of weak form efficiency, daily averages of adjusted returns of investors are independent to their lagged values. Here, we firstly estimate a first-order Autoregressive Model AR(1) in order to test whether the adjusted returns are autocorrelated. The AR(1) model is expressed by

where $\bar{r}_{t}$ is defined in Equation (3), $\bar{r}_{t !}$ is the lagged value of $\bar{r}_{t}$ and $u_{t}$ is the error term. In order to say that the market is efficient, slope coefficient $b_{1}$ should not be significant. That is, we should not have any relationship between the daily average of adjusted return and its 1 lag to ensure the market efficiency in a weak form.

One of the implications of Efficient Market Hypothesis is that both the daily returns of market beaters and daily returns of market beatens are near zero. We define market beaters (beatens) as the group of investors who overperform (underperform) the market. That is, investors who have positive (negative) adjusted return are called as market beaters (beatens). Here, we want to test whether the difference between the returns of market beaters and returns of market beatens are zero or not. The aim of this test is to see the evaluation of the market efficiency. Therefore, we use standard $t$ test for each day. The null hypothesis of the test is that the average of adjusted returns of market beaters equal to the average of adjusted returns of market beatens. The direction of the daily $t$ test values indicates the evaluation of efficiency in the market.

Due to the randomness in stock prices, the Efficient Market Hypothesis remarks that half of all investors should beat the market in a given period (see Damodaran (2003)). According to the results of Barber and Odean (2000), 49.3 percent of investors beat the market. Moreover, other half of investors is expected to underperform the market. In order to observe whether the market is efficient or not, we prefer to conduct a test for the null hypothesis of "Number of Market 
Beaters" equals to "Number of Market Beatens". In other words, we want to examine that the proportion of the number of market beaters and beatens is 1 or not.

Another implication of an efficient market is that the investors should not be able to beat the market consistently. To put it another way, if the market is efficient, no group of investors systematically can get higher returns than the market. Here, we investigate market beating performance of each investor. The performance criterion is defined as the maximum consecutive days that each investor beats the market. In the literature, consecutive series of adjusted return movements without a sign reversal is defined as a run (Poshakwale (1996)). Hence the serried market beating (beatening) refers to positive (negative) run. Additionally, for a given day, we are interested with average of the length of the runs of investors. So, we want to see the historical movement of average length of runs in order to evaluate the efficiency in the market.

\subsubsection{ANALYSIS FOR TRADING BEHAVIOR OF INVESTORS}

To begin the analysis, following Barber and Odean (2001), we first define the turnover as follows:

(5)

where TradedValue $\underline{\text { it }}_{\text {is }}$ is calculated as the total trade at day $t$ in terms of market value for each investor $j$. And, $\overline{P S i z e}_{j}$ represents the monthly average of end-of-day portfolio holdings in terms of market value for each investor $j$.

Having calculated market adjusted daily turnover in (5) for each day $t[1,2, \ldots, 1259]$, we calculate the daily average turnover $\overline{\text { Turnover }}_{t}$ over investors as:

(6)

\subsubsection{RELATIONSHIP BETWEEN THE MARKET EFFICIENCY AND TURNOVER}

To show the relationship between efficiency and turnover, we employ daily efficiency and turnover values. Efficiency in a given day is defined by using three different measures and one of them use the difference between the average value of adjusted return of market beaters and beatens. In a similar way, daily turnover is described as the daily average of the turnover values of investors. The analysis of the link between the daily values of efficiency and turnover provide us to test our claim mentioned above.

\section{RESULTS}

For all estimations in this section, we use the data which is mentioned in the previous section. Estimation results are also separated as in the previous section. All of the analyses are performed using Stata software. The respective codes and commands are used for each estimation. The main parts of the estimation tools and results are presented here. The detailed results, codes etc. are available up on request. 


\section{I. ADJUSTED RETURNS}

Descriptive statistics for the adjusted returns of investors are illustrated in Table 1 and 2. Returns are adjusted by the BIST 100 Index (main broad value-weighted stock index of Borsa Istanbul's equity market). The statistics are separated by the type of investors such as Individual and Institutional. When we divide the Individuals data across genders, women significantly outperform men in terms of average market adjusted returns. For the institutional investors, foreign investors have better performance than domestic investors in the overall.

Table I: Daily Return Statistics for Individual Investors

\begin{tabular}{|l|l|l|l|}
\hline Return Statistics & All & Women & Men \\
\hline$\#$ & $24993^{*}$ & 6049 & 18944 \\
\hline Mean & $0.022 \%$ & $0.032 \%$ & $0.019 \%$ \\
\hline St. Dev. & $0.002 \%$ & $0.003 \%$ & $0.002 \%$ \\
\hline
\end{tabular}

* The remaining number of investors after calculations.

Table 2: Daily Return Statistics for Institutional Investors

\begin{tabular}{|l|l|l|l|}
\hline Return Statistics & All & Domestic & Foreign \\
\hline$\#$ & $5444^{*}$ & 4246 & 1198 \\
\hline Mean & $-0.024 \%$ & $-0.033 \%$ & $0.006 \%$ \\
\hline St. Dev. & $0.008 \%$ & $0.008 \%$ & $0.02 \%$ \\
\hline
\end{tabular}

* The remaining number of investors after calculations.

\subsection{EVALUATION OF MARKET EFFICIENCY}

In order to see the evaluation of market efficiency, we analyze how the market is efficient in time using several test and statistics.

Firstly, we use AR(1) model expressed in Equation (4) to test whether the adjusted returns are autocorrelated or not. Test results are given in Table 3. According to the results for both of individual and institutional investors, slope coefficients are not found to be significant. That is, there is no relationship between the daily average of adjusted return and its 1 lag. Furthermore, the independence between daily averages of adjusted returns and their lagged values can be seen in Figure 1. Therefore, we ensure the market efficiency for Borsa Istanbul in a weak form.

Table 3: Test Results for Autocorrelation

\begin{tabular}{|l|l|l|}
\hline Coefficient & Individual & Institutional \\
\hline & 0.0001 & -0.0287 \\
& $(0.77)$ & $(-1.02)$ \\
\hline & 0.0323 & 0.0001 \\
& $(1.15)$ & $(0.72)$ \\
\hline $\mathrm{R}^{2}$ & 0.001 & 0.001 \\
\hline
\end{tabular}

Note: The t statistics are in parentheses. 
Individual Investors

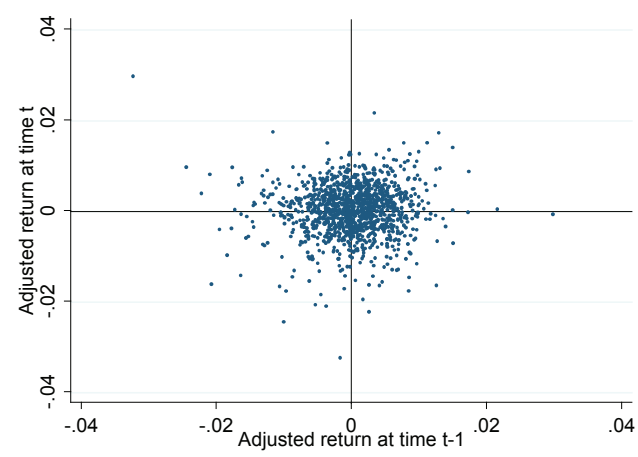

Institutional Investors

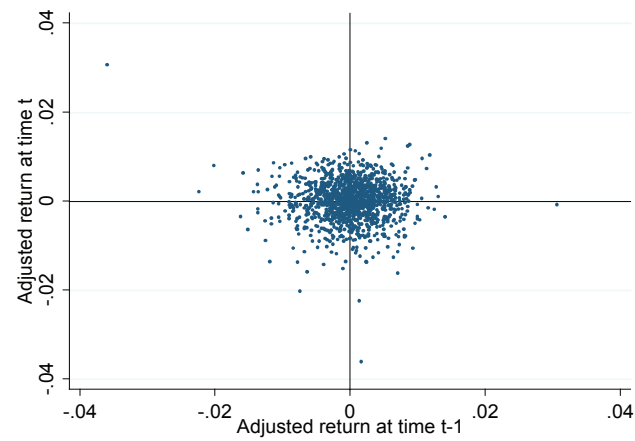

Figure I: Daily Average of Adjusted Returns

Efficiency Measure 1a: Another implication of the efficiency can be tested by looking the difference between the average of adjusted returns of market beaters and market beatens. Here we define efficiency for a given date $t$ with the following way:

$$
\text { Efficiency } t_{t}=\left[(\text { Average Adjusted Return of Beaters })_{t}-(\text { Average Adjusted Return of Beatens })_{t}\right]^{-1}
$$

Individual Investors

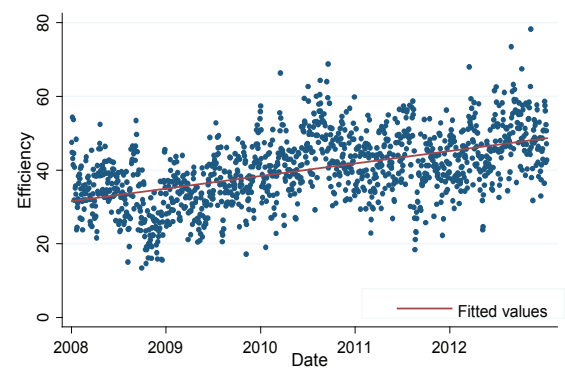

Institutional Investors

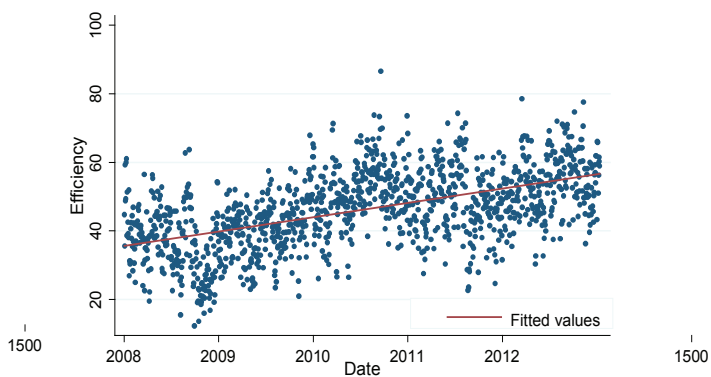

Figure 2: Evaluation of Efficiency

The movement of efficiency is illustrated in Figure 2. As it can be seen, inefficiency in Borsa Istanbul created by each investor type decreases as the time goes by.

Efficiency Measure 1b: Furthermore, we use standard t test for each day in order to capture the direction of market efficiency. The structure of the test is following:

$\mathrm{H}_{0}$ : Average Adjusted Return of Beaters = Average Adjusted Return of Beatens

$\mathrm{H}_{\mathrm{A}}$ : Average Adjusted Return of Beaters $\neq$ Average Adjusted Return of Beatens 
The results of the daily t test are demonstrated in Figure 3. Decreasing daily t test values for both types of investors indicate that, even though there is still an inefficiency, the efficiency in Borsa Istanbul increases in the process of time.

Individual Investors

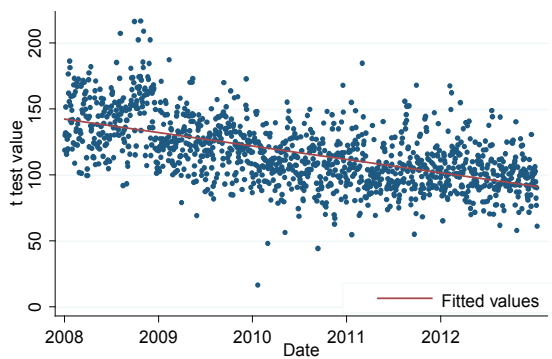

Institutional Investors

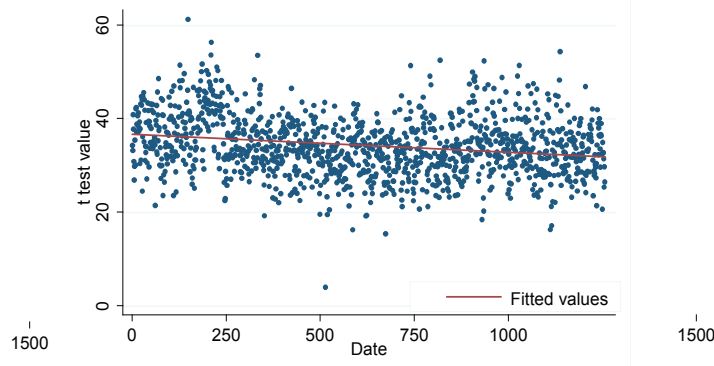

Figure 3: Evaluation of Efficiency Using Standard t Test

Efficiency Measure 2: In order to observe whether the market is efficient or not in a strong form, we prefer to conduct another test which has the null hypothesis of "Number of Market Beaters" equals to "Number of Market Beatens". In other words, we want to examine that the proportion of the number of market beaters and beatens is 1 or not.

Individual Investors

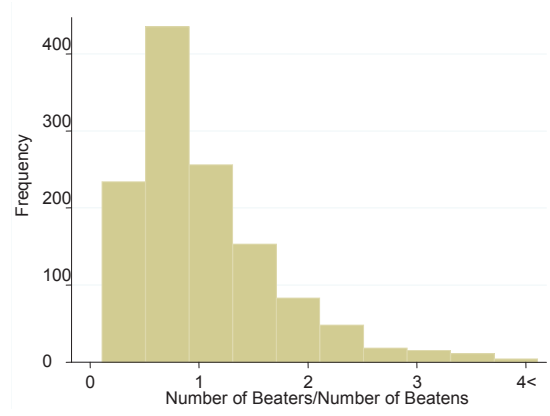

Institutional Investors

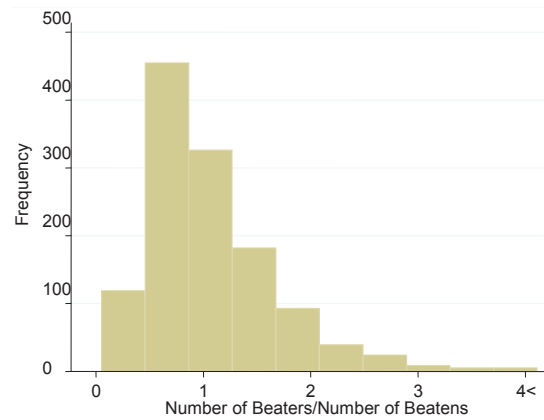

Figure 4: Proportion Of The Number Of Market Beaters And Beatens

The frequency distributions of the proportion of the number of market beaters and beatens for both of investor types are illustrated in Figure 4. Here, there are some outliers on the right tale for both analyses. So, we dropped 2,5\% from right tail of each data. Then the test results ${ }^{1}$ indicate that we cannot reject the hypothesis of "Mean proportion of the Number of Market Beaters

1 The value of $\mathrm{t}$ test for individual and institutional investors are -0.378 and 1.234 respectively. 
and Beatens=1" for each investor type. Therefore, one of the implications of the Efficient Market Hypothesis which indicates that the number of beaters and beatens in the market are equal, points out the efficiency in Borsa Istanbul.

Efficiency Measure 3: Most popular definition of market efficiency is that no group of investors should be able to beat the market consistently. Here, we investigate market beating performance of each investor type in Borsa Istanbul. The information of maximum consecutive days that each investor beats the market is presented in Figure 5. When it is considered that we employ 1259 weekdays in our analysis here, it would be a signal for the efficiency that the maximum period of beating for almost all investors in Borsa Istanbul is less than 20 days.

Individual Investors

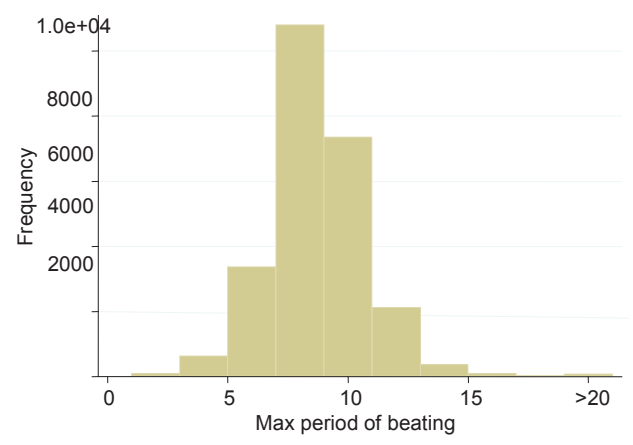

Institutional Investors

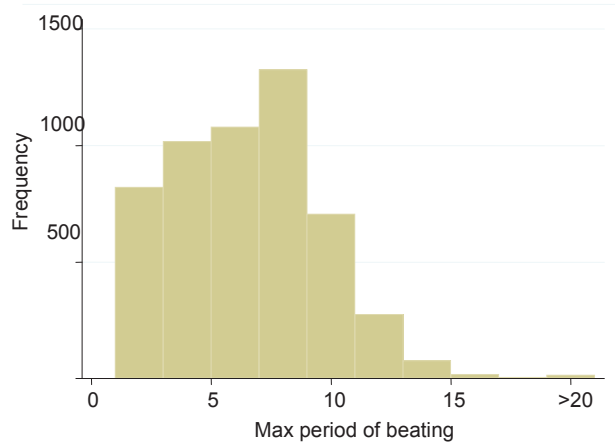

Figure 5: Beating Performance of Investors

We are also interested with average of the length of the runs of investors for a given day. So, we want to see the historical movement of average length of positive runs in order to evaluate the efficiency in the market. Reducing average length value of positive runs in time for both types of investors signifies the convergence to the market efficiency in Borsa Istanbul.

Individual Investors

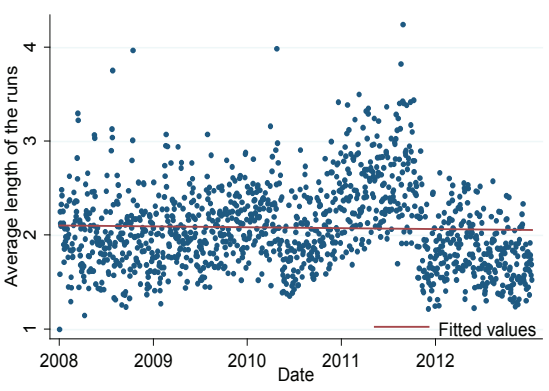

Institutional Investors

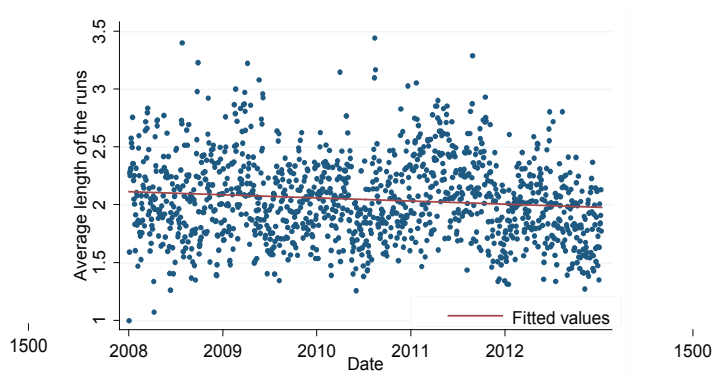

Figure 6: Movement of the length of positive runs 


\subsection{ANALYSIS FOR TRADING BEHAVIOR OF INVESTORS}

Descriptive statistics for the turnover of investors in Borsa Istanbul are illustrated in Table 4 and 5. The variable "Turnover" which is defined in equation (6) is adjusted in a way that values higher than $100 \%$ are dropped from the sample. The statistics are separated by the type of investors such as Individual and Institutional. When we divide the Individuals investors across gender, women have slightly higher turnover than men. For the institutional investors, we select "Domestic Funds" as a representative institutional type due to the restrictions on portfolio data.

Table 4: Daily Turnover Statistics for Individual Investors

\begin{tabular}{|c|c|c|c|}
\hline Turnover Statistics & All & Women & Men \\
\hline$\#$ & 22284 & 5449 & 16835 \\
\hline Mean & 0.3790 & 0.3794 & 0.3789 \\
\hline St. Dev. & 0.0017 & 0.0035 & 0.0019 \\
\hline
\end{tabular}

Table 5: Daily Turnover Statistics for Institutional Investors

\begin{tabular}{|c|c|c|c|}
\hline Turnover Statistics & All & Domestic & Foreign \\
\hline$\#$ & 353 & 353 & - \\
\hline Mean & 0.2069 & 0.2069 & - \\
\hline St. Dev. & 0.0139 & 0.0139 & - \\
\hline
\end{tabular}

\subsection{RELATIONSHIP BETWEEN MARKET EFFICIENCY AND TURNOVER}

As mentioned in Section 2, we claim that market efficiency and turnover have reverse relationship. Since we previously showed that Borsa Istanbul converges to be an efficient market in the period of 2008-2012, here we want to observe whether the turnover decreases or not as the market becomes efficient. In order to show the relationship between efficiency and turnover, we use daily efficiency and turnover values in Borsa Istanbul. The analysis of the link between the daily values of efficiency and turnover provide us to test our claim mentioned above. Daily turnover $^{2}$ is described as the daily average of the turnover values of investors (Equation (6)). For the robustness check, we take following different characterizations of efficiency which are described in Section 3.2.

Efficiency characterization 1 is measured as:

Efficiency $1=(\text { Average Adjusted Return of Beaters - Average Adjusted Return of Beatens })^{-1}$

Efficiency characterization 2 is measured as:

2 Since we deal with the turnover values, we use "Domestic Funds" as a representative institutional type due to the reason explained in Section 3.3. 
Efficiency $2=[\mathrm{t}$ value of the test of (Average Adjusted Return of Beaters=Average Adjusted Return of Beatens) $]^{-1}$

Efficiency characterization 3 is measured as:

$$
\text { Efficiency3 }=[\text { Average Length of Runs }]^{-1}
$$

Turnover values for time quintiles based on different efficiency characterizations are illustrated in Figure 7. Records of days are sorted into quintiles based on efficiency characterization. Quintile 1 contains days with the lowest efficiency value; quintile 5 contains days with the highest.

Individual Investors
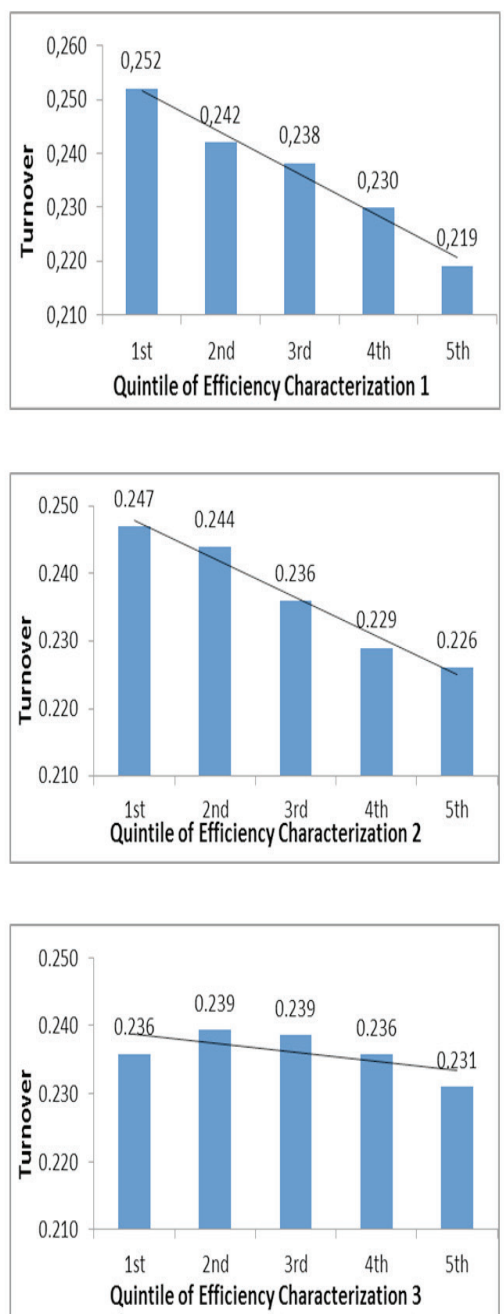

Institutional Investors
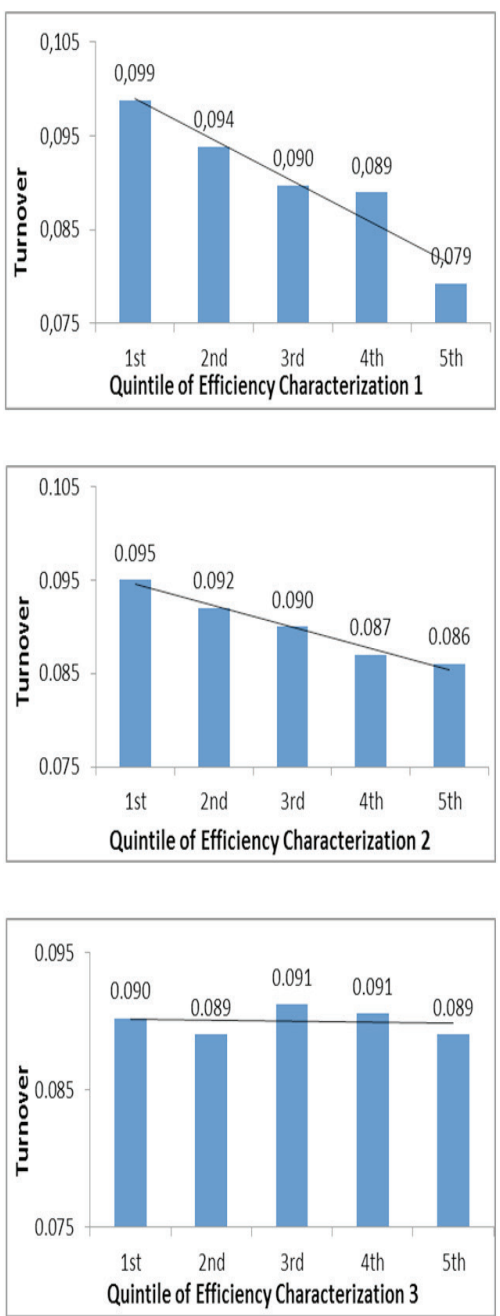

Figure 7: Relationship between Efficiency and Turnover 
We also run a test of the hypothesis that Mean Value of Turnover for 1st quintile $>5$ th quintile for each analysis above. All the test results indicate that the mean value of turnover for 1st quintile of efficiency is higher than the mean value of turnover for 5 th quintile of efficiency ${ }^{3}$. Considering these results and trends in each graph above, we have evidence that the trading motivation of both types of investors moves down as the efficiency in the market increases.

That is, average turnover decreases as the market becomes efficient. Damodaran (2003) supports our claim with the following statement: "In an efficient market, a strategy of minimizing trading, i.e., creating a portfolio and not trading unless cash was needed, would be superior to a strategy that required frequent trading".

\section{CONCLUSION}

The high volume of trade in stock markets has been one of the main discussion topics in finance theory. One of the most discussed issues for the finance theory is whether a financial market provides efficiency. This paper enters into this discussion with evaluating market efficiency in a given stock exchange, namely Borsa Istanbul using investor data. In line with this objective, we first set up several measures of market efficiency by the means of daily data for both individual and institutional data covering five years.

With the help of our efficiency characterizations and turnover data of investors, we reach that the efficiency and the turnover are negatively correlated. That is, the trading motivation of both individual and institutional investors plunges down as the efficiency in the market increases. The data also suggests that the efficiency in the given stock market, Borsa Istanbul, has increased after the crisis, showing that the effect of the crisis has vanished as time passes.

\section{REFERENCES}

BARBER, B. M., and ODEAN, T. 2000. “Trading is hazardous to your wealth: The common stock investment performance of individual investors", Journal of Finance, 55, 773-806.

BARBER, B. M., and ODEAN, T. 2001. "Boys Will Be Boys: Gender, Overconfidence, and Common Stock Investment”, Quarterly Journal of Economics, 116, 261-292.

BASU, S. 1977. "Investment performance of common stocks in relation to their price-earnings ratios: A test of the efficient market hypothesis", The Journal of Finance, 32(3), 663-682.

BENOS, A. V. 1998. "Aggressiveness and survival of overconfident traders", Journal of Financial Markets, 1, 353-383.

CHUANG, W.I., and SUSMEL, R. 2011. "Who is the more overconfident trader? Individual vs. Institutional Investors", Journal of Banking and Finance, 35, 1626-1644.

COVAL, J. D., HIRSHLEIFER, D. A., and SHUMWAY T. 2005. “Can Individual Investors Beat the Market?”, Working paper, University of Michigan.

3 For the first characterization, the values of $\mathrm{t}$ tests for individual and institutional investors are 19,26 and 11,06 respectively. For the second characterization, the values of $\mathrm{t}$ tests for individual and institutional investors are 11,42 and 5,09 respectively. 
DAMODARAN, A. 2002. "Investment Valuation: Tools and Techniques for Determining the Value of Any Asset", Second edition, John Wiley \& Sons.

DAMODARAN, A. 2003. "Investment Philosophies: Successful Strategies and the Investors Who Made Them Work", Wiley, Hoboken, NJ.

FAMA, E. F. 1970. "Efficient capital markets: a review of theory and empirical work", Journal of Finance, $25,383-417$.

FAMA, E. F. 1991. "Efficient Capital Markets II”, Journal of Finance, 46, 1575-1671.

GLASER, M. and WEBER, M. 2007. "Overconfidence and trading volume”, Geneva Risk and Insurance Review, 32, 1-36.

JAHNKE, W. W. 1994. "Requiem for Efficient Market Theory”, The Journal of Investing, 3, 25-9.

ODEAN, T. 1998. "Volume, Volatility, Price, and Profit When All Traders Are above Average", Journal of Finance, 53, 1887-1934.

ODEAN, T. 1999. “Do investors trade too much?”, American Economic Review, 1279-1298.

POSHAKWALE, S. 1996. "Evidence on weak form efficiency and day of the week effect in the Indian stock market", Finance India, 10(3), 605-616.

STATMAN, M. 2011. “Efficient markets in crisis”, Journal of Investment Management, 9, 4-13. 